\title{
Hume's Rhetorical Strategy: three views
}

Daryl Ooi

(This is a preprint of an article whose final and definitive form will be published in The

Journal of Scottish Philosophy. The published article is available online at:

https://www.euppublishing.com/doi/abs/10.3366/jsp.2021.0310).

\section{Introduction ${ }^{1}$}

In the Fragment on Evil, Hume remarks, "Should I enumerate all the evils, incident to human life, and display them, with eloquence, in their proper colours, I should certainly gain the cause with most readers, who would be apt to despise, as frivolous, all the pleasures, which could be placed in opposition to them" (FE 111). ${ }^{2}$ However, Hume announces that he will not pursue this rhetorical strategy, explaining, "I take no advantage of this circumstance, and shall not employ any rhetoric in a philosophical argument, where reason alone ought to be hearkened to." However, in the Dialogues (DNR 11), when Hume (or Philo) presents the inferential (DNR 11.2-13) and evidential

\footnotetext{
${ }^{1}$ I would like to thank Qu Hsueh Ming and an anonymous reviewer for their helpful comments on an earlier version of this paper.

${ }^{2}$ References to the Fragment on Evil are from Coleman 2007 (FE), Dialogues Concerning Natural Religion are from Coleman 2007 (DNR), Letters to Gilbert Elliot of Minto are from Coleman 2007 (HL), A Treatise on Human Nature are from Selby-Bigge 1975, revised by Nidditch (THN), Dissertation on the Passions are from Beauchamp 2007 (P), On Eloquence are from Miller 1987 (EL) and Enquiry Concerning Human Understanding are from Millican 2008 (EHU).
} 
(DNR 11.14-16) arguments from evil, he employs precisely this rhetorical strategy of enumerating and displaying the evils incident to human life. ${ }^{3}$

I discuss three interpretations that might account for Hume's use of the rhetorical strategy. On the Evolutionary Interpretation, Hume's willingness to employ the rhetorical strategy in the Dialogues is merely apparent. Hume does not employ the rhetorical strategy in DNR 11. Rather, what appears to be a use of the rhetorical strategy is merely a presentation of the inferential and evidential arguments themselves. On the Rhetorical Interpretation, Hume does not endorse the evidential argument from evil. Instead, the evidential argument is a platform for Hume to employ the rhetorical strategy for the purpose of Philo gaining the cause with his readers. Finally, the Coherence Interpretation. Hume's use of the rhetorical strategy serves both an argumentative and a rhetorical function. Given that the Dialogues is presented as an educational activity for Pamphilus, and assuming that Philo represents Hume, Philo's use of rhetoric in the Dialogues has implications for Hume's views on education, which I discuss in conclusion. ${ }^{4}$ Finally, I evaluate all three interpretations and suggest that the Coherence Interpretation is the most promising.

\section{The Rhetorical Strategy}

The Fragment is generally accepted as "a remnant from a manuscript Hume was composing around the time he was completing his Treatise" (Stewart 1995, 160). Hume's primary concern in the Fragment is with the conclusions we may draw about God's benevolence from the inferential argument from natural phenomena. Hume holds that the only way of deciding whether God is benevolent is to infer it from phenomena. If pleasure predominates over pain, we may conclude that God is benevolent. However, if pain predominates over pleasure, then it follows that God is

\footnotetext{
${ }^{3}$ In this essay, I follow the common opinion of commentators that Philo is Hume's spokesperson.

${ }^{4}$ See Krause 2016 for a helpful discussion on the role of Pamphilus in the Dialogues.
} 
not benevolent. Hume himself adopts moral agnosticism. However, he begins to develop an incomplete and premature version of the evidential argument from evil. In particular, Hume observes the seemingly indifferent distribution of pain and pleasure across the universe, noting that neither prevails much above the other (FE 112). However, Hume concludes nothing about God's benevolence from this observation.

When Hume discusses the inferential argument, he makes a clear distinction between two different tools: philosophical argument and rhetoric. Hume's philosophical argument from evil can be briefly summarised as follows:

P1 - If God is benevolent, then pleasure will predominate the world. If God is not benevolent, then pain will predominate the world.

$\mathrm{P} 2$ - We are not in a position epistemically to determine whether pain or pleasure predominates.

$\mathrm{C}$ - Therefore, we are not in a position epistemically to determine whether God is benevolent or not benevolent.

Nevertheless, Hume reports an interesting psychological reflective observation: according to his experience, when he reflects impartially, it seems to him that pain predominates. Hume offers a psychological explanation for this observation: experiences of pain tend to be more intense than experiences of pleasure, and what is more intense has a more powerful influence on our imagination. Therefore, Hume concludes that he has a tendency to believe that pain predominates. ${ }^{5}$

\footnotetext{
5 "What is evil alarms us more, and makes more lasting impression than what is agreeable; which we readily receive without enquiry, and which we think ourselves in some measure, entitled to. Besides, the greater intenseness of our pains has a much more powerful influence on the imagination than the frequency of our pleasures; and it is almost impossible for us to make a just compensation betwixt them." (FE 111).
} 
Then, Hume adds,

Should I enumerate all the evils, incident to human life, and display them, with eloquence, in their proper colours, I should certainly gain the cause with most readers, who would be apt to despise, as frivolous, all the pleasures, which could be placed in opposition to them. Victuals, wine, a fiddle, a warm bed, a coffeehouse conversation make a pitiful figure, when compared with racks, gravels, infamy, solitude, and dungeons. But I take no advantage of this circumstance, and shall not employ any rhetoric in a philosophical argument, where reason alone ought to be hearkened to. (FE 111)

Hume recognizes that if he uses eloquence and rhetoric to list, describe and paint a verbal picture of the evils in the world, he would be able to convince most of his readers. Call this the rhetorical strategy. However, Hume announces that he will not use this strategy, noting that he "shall not employ rhetoric in a philosophical argument, where reason alone ought to be hearkened to." In this case, Hume's reason (the arguments of computation and comparison) yields a different conclusion from his psychological observations: the former yields the conclusion that we are not in an epistemic position to determine whether pain or pleasure predominate, and the latter yields the conclusion that pain predominates. Hume decides not to employ the rhetorical strategy in support of the psychological observation.

In order to understand the rhetorical strategy, we may consider the role of rhetoric in Hume's other works. ${ }^{6}$ In his short essay On Eloquence, Hume acknowledges the persuasive power of rhetoric and eloquence. Cicero's eloquence, for instance, allows him to charm Julius Caesar,

\footnotetext{
${ }^{6}$ For a helpful treatment on Hume's use of rhetoric, see Hanvelt 2012.
} 
and thereby, Caesar is "constrained" to change his mind, and to free a criminal who, prior to Cicero's pleas, Caesar intended to condemn (EL 14). Hume's views on the effectiveness of eloquence in persuasion are supported by his philosophy of mind. Hume explains that "Nothing is more capable of infusing any passion into the mind, than eloquence, by which objects are represented in their strongest and most lively colours. We may of ourselves acknowledge, that such an object is valuable, and such another odious; but 'till an orator excites the imagination, and gives force to these ideas, they may have but a feeble influence either on the will or the affections" (THN 2.3.6.7, see P 6.16). In exciting the audience's imagination, ideas appear with greater force, and have greater influence (or constrain, see EL 14) on the audience's affections, than would argument. According to Hume's theory of mind, belief consists in "A lively idea related to or associated with a present impression" (THN 1.3.7.5). Rhetoric lends ideas force and liveliness in the minds of the audience. Rhetoric is thus an effective tool for facilitating belief. This is why Cicero is able, through his eloquence, to convince Caesar to change his mind.

Yet, as Hanvelt argues, Hume is "ambivalent" about the use of rhetoric. When rhetoric is used effectively, ideas appear with force, liveliness and vivacity in the minds of one's audience, producing belief. But it can be used to form both true and false beliefs (Hanvelt 2012, 39). Thus, rhetoric is both compatible and incompatible with reason.

Hume recognizes that if he were to employ the rhetorical strategy, that is, to "enumerate all the evils and display them, with eloquence, in their proper colours," he would be able to persuade most of his audience. His unwillingness to employ the rhetorical strategy indicates his reservations about rhetoric. While rhetoric might be effective and useful in convincing his audience, he is unwilling to employ it in a philosophical argument where we ought to appeal to reason alone. 
In DNR 11, Hume presents inferential and evidential arguments from evil. The inferential argument is that, given unnecessary evil, we cannot infer from phenomena to God's benevolence (DNR 11.12). But in presenting the inferential argument Hume enumerates four different causes of evil. In doing so, he presents them in their proper colours, so to speak:

All animals might be constantly in a state of enjoyment; but when urged by any of the necessities of nature, such as thirst, hunger, weariness; instead of pain, they might feel a diminution of pleasure, by which they might be prompted to seek that object, which is necessary to their subsistence. Men pursue pleasure as eagerly as they avoid pain; at least, might have been so constituted. It seems, therefore, plainly possible to carry on the business of life without any pain. Why then is any animal ever rendered susceptible of such a sensation? If animals can be free from it an hour, they might enjoy a perpetual exemption from it; and it required as particular a contrivance of their organs to produce that feeling, as to endow them with sight, hearing, or any of the senses. (DNR 11.6)

In enumerating the four different causes of evil in support of the inferential argument in the Dialogues, Hume does precisely what he said he would not to do in the Fragment: he "enumerate[s] all the evils, incident to human life, and display them, with eloquence, in their proper colours..." (FE 111). Moreover, in his presentation of the evidential argument, Hume deploys the rhetoric and eloquence he rejects in the Fragment:

Look round this universe. What an immense profusion of beings, animated and organized, sensible and active! You admire this prodigious variety and fecundity. But inspect a little more narrowly these living existences, the only beings worth regarding. How hostile and destructive to each other! How insufficient all of them 
for their own happiness! How contemptible or odious to the spectator! The whole presents nothing but the idea of a blind Nature, impregnated by a great vivifying principle, and pouring forth from her lap, without discernment or parental care, her maimed and abortive children. (DNR 11.13).

How do we explain Hume's change of attitude towards the rhetorical strategy? I propose three interpretations that account for Hume's use of the rhetorical strategy in his discussion of the moral attributes of God in the Dialogues, despite his rejection of the strategy in the Fragment. I conclude by discussing the relevance of these interpretations for Hume's views on education.

\section{First Interpretation: Evolutionary Interpretation}

The Dialogues was written long after the Fragment. Perhaps Hume's views about the rhetorical strategy evolved. Perhaps the Dialogues represent Hume's mature views. Perhaps the arguments in the Fragment merely foreshadow or precede the arguments in the Dialogues (e.g., Stewart 2003, 57 fn 28; Stewart 2005; Lorkowski 2016, 262-263 etc.). Indeed, one part of the evidential argument from the Dialogues may have developed out of a small passage in the Fragment. In the Fragment, Hume acknowledges that his primary argument does not establish knowledge about whether God is benevolent and so he briefly considers an alternative strategy.

\section{Fragment on Evil}

Pains and pleasures seem to be scattered indifferently through life, as heat and cold, moist and dry are dispersed through the

\section{Dialogues Concerning Natural Religion}

But if we consider, on the other hand, the perfect uniformity and agreement of the parts of the universe, we shall not discover in it any 
universe; and if the one prevails a little above the other, this is what will naturally happen in any mixture of principles, where an exact equality is not expressly intended. On every occasion, nature seems to employ either. (FE 112, emphasis mine) marks of the combat of a malevolent with a benevolent being. There is indeed an opposition of pains and pleasures in the feelings of sensible creatures: but are not all the operations of Nature carried on by an opposition of principles, of hot and cold, moist and dry, light and heavy? The true conclusion is, that the original source of all things is entirely indifferent to all these principles, and has no more regard to good above ill than to heat above cold, or to drought above moisture, or to light above heavy. (DNR 11.14, emphasis mine)

On this reading, the evidential argument appears in the Fragment, while the passage from the Dialogues develops the argument further. The inferential and evidential arguments in the Dialogues are developed from the arguments in the Fragment and the enumeration of evils is merely a more detailed presentation of Hume's earlier arguments. On this reading, Hume develops the inferential and evidential arguments sincerely in the Dialogues. He is not enumerating evils rhetorically, in order to gain the cause with his readers; he is not appealing to the readers' imagination instead of their reason. He is not employing "rhetoric in a philosophical argument, where reason alone ought to be hearkened to." 
In support of this reading, note that the arguments presented in the Dialogues are structured as arguments. The inferential argument begins with the claim that there are four circumstances (causes of evil), none of which appear to human reason to be "necessary or unavoidable" (DNR 11.5). Hume then enumerates these causes of evil in turn (DNR 11.6-11). ${ }^{7}$ Here Hume anticipates the responses of proponents of best-of-all-possible-worlds theodicies or greater-good theodicies, such as Leibniz, according to which the evils in the world are counterbalanced by another, greater good. Cleanthes hints at this strategy in DNR 11.1, which sets the stage for Philo's response. ${ }^{8}$ In arguing that the causes of evil are unnecessary, Hume is presenting an argument against such theodicies, and Philo is presenting a response to Cleanthes.

Hume's conclusion to the inferential argument reflects the general moral agnosticism of the Fragment. He is willing to admit that these circumstances do not prove that pain predominates, or that God is not benevolent: "I am Sceptic enough to allow, that the bad appearances, notwithstanding all my reasonings, may be compatible with such attributes as you suppose" (DNR 11.12). Hume concedes that the list of unnecessary causes might only appear unnecessary. There is the logical possibility of a necessary reason for these causes beyond our human understanding.

The evidential argument is presented in DNR 11.13-15 in a more developed form compared to its appearance in the Fragment. The argument is more complete and the conclusion is clearer in the Dialogues. In the Fragment, Hume simply observes the seemingly indifferent distribution of pain and pleasure, none of which prevails much above the other, without concluding how the

\footnotetext{
${ }^{7}$ It appears that much of the material from the inferential argument in the Fragment (such as the problems of computation and comparison) was used by Hume in DNR 10 to establish the same conclusion.

${ }^{8}$ Cleanthes remarks, "But supposing the Author of Nature to be finitely perfect, though far exceeding mankind; a satisfactory account may then be given of natural and moral evil, and every untoward phenomenon be explained and adjusted. A less evil may then be chosen, in order to avoid a greater: Inconveniencies be submitted to, in order to reach a desirable end: And in a word, benevolence, regulated by wisdom, and limited by necessity, may produce just such a world as the present" (DNR 11.1).
} 
indifferent distribution relates to the moral attributes of God. In the Dialogues, Hume makes the same observation and finds: "The true conclusion is, that the original source of all things is entirely indifferent to all these principles, and has no more regard to good above ill than to heat above cold, or to drought above moisture, or to light above heavy" (DNR 11.14). That is, the indifferent scattering of pain and pleasure makes it most probable that God is indifferent to pain and pleasure.

On the Evolutionary Interpretation, Hume's enumeration of the evils is evidence in support of the inferential and evidential arguments in the Fragment. The additions he makes in DNR 11 to the arguments first presented in the Fragment are provided for argumentative reasons. In DNR 11, Hume strengthens the inferential argument from the Fragment by providing a second argument. In the Fragment, Hume argues that the problems of computation and comparison prevent us from inferring any knowledge about God's moral attributes. In the Dialogues, he strengthens this conclusion by arguing that the existence of unnecessary causes of evil block any inference from phenomena to the benevolence of God. And while Hume observes the indifferent scattering of pain and pleasure in the Fragment, he draws a conclusion from this observation in the Dialogues.

There are, however, two problems facing this reading. First, the evidential conclusion (in the Dialogues) appears incommensurable with the inferential conclusion (in both the Fragment and Dialogues). In both texts, Hume's moral agnosticism is clear: he holds that we are unable to know anything about God's moral attributes. This conclusion, however, is inconsistent with the moral atheism of the conclusion to the evidential argument: that we know something about God's moral attributes, namely, that God is morally indifferent. If the enumeration of evils is intended for solely argumentative purposes, and if Hume endorses both the inferential and evidential arguments, we would expect the conclusions of the two arguments to be compatible. 
A proponent of the Evolutionary Interpretation might argue that Hume is a moral agnostic in the sense that he recognizes the possibility of potential counterarguments he has not considered, or is unable to consider. His claim is modest: given current phenomena, if he had to a propose a hypothesis, it would be moral atheism. The strategy is analogous to arguments based on the scientific method: there may be new evidence, or evidence to which we have no access. However, given the data that we currently possess, we are within our epistemic rights to make tentative, provisional claims.

Thomas Holden raises a second concern with the Evolutionary Interpretation. Holden argues that the evidential argument cannot be "completely sincere" (Holden 2010, 175-176). First, the reasoning is "out of character" for Hume, being an instance of the type of theological reasoning he rejects in both the Enquiry and the Dialogues (Holden 2010, 170-171). Second, it violates Hume's mitigated scepticism (ibid.). I might add that it is in clear violation of the arguments from computation and comparison that Hume endorses in both the Fragment and the Dialogues. Third, Holden argues that the evidential argument falls prey to some of Philo's specific objections to Cleanthes earlier in the Dialogues (Holden 2010, 171-172). Finally, Holden argues that the evidential argument "seems quite weak on its own terms" (Holden 2010, 173-174).

One response to Holden distinguishes between the inferential argument and the evidential argument. A proponent of the Evolutionary Interpretation may argue that that inferential argument develops on the basis of philosophical reasoning, while the evidential argument does not. If this response is persuasive, and if Holden is correct, then we need another interpretation to explain the role of the evidential argument in the Dialogues in relation to its less mature counterpart in the Fragment. In the next section, I propose this second reading, based on the rhetorical strategy, to account for the function of the evidential argument in the Dialogues. 


\section{Second Interpretation: Rhetorical Interpretation ${ }^{9}$}

According to Holden, Hume cannot seriously endorse the evidential argument. The Rhetorical Interpretation agrees. On this reading, the evidential argument merely introduces Hume's (or Philo's) rhetorical strategy. In fact, the evidential argument functions as a masquerade for Hume's use of the rhetorical strategy. Hume could be employing the rhetorical strategy for a variety of reasons: to showcase his rhetorical prowess, to make jest or satire at religious leaders who use rhetoric over reason, to be sarcastic, or simply for fun (this would not be unexpected from Philo, as observed by Cleanthes, e.g., DNR 11.18-19). ${ }^{10}$ Consider one possible reason for Philo's use of rhetoric: to mock religious leaders. Philo begins his discussion on the moral attributes of God by noting that "a talent of eloquence and strong imagery is more requisite than that of reasoning and argument" in "bringing every one to a due sense of religion" (DNR 10.2). He continues: "For is it necessary to prove, what every one feels within himself? 'Tis only necessary to make us feel it, if possible, more intimately and sensibly" (DNR 10.2). ${ }^{11}$ In fact, he explains that the most effective way is therefore to use eloquence to bring about the sense of the misery and wickedness of men.

Philo ends his discussion of the moral attributes by returning to this observation (DNR 11.20). He criticises the divines who use rhetoric at the expense of reason. They used eloquence and strong imagery to emphasize the misery and wickedness of men. Their negligence of just reasoning is demonstrated by the fact that they are willing to change their position (initially

\footnotetext{
${ }^{9}$ Morrisroe Jr. sees Hume as responding to Butler in these passages. He thinks that for Hume, "If logical argument and the indication of discrepancies in the argument from analogy could not weaken it, Hume had to find some method by which the readers were to be made aware of what he saw to be the errors of the argument" (Morrisroe Jr., 1969, 135-136). He thinks that the method Hume uses is rhetoric, through "imagery and metaphor," but interestingly, he thinks Hume does this through Demea's language. The rhetorical interpretation does not particularly disagree with Morrisroe Jr. since it does not make any claim concerning Demea's use of rhetoric. In fact, if Hume (not just Philo) is intent of using rhetoric, it would be unsurprising if he used all his characters to as instruments of the rhetorical strategy.

${ }^{10}$ For a helpful discussion on Hume's intentions in the Dialogues, see Samuel Clark 2013.

${ }^{11}$ See also DNR 10.4.
} 
emphasizing the wickedness of men; and now focusing on the pleasures of this life), adopting whichever position brings about the best result (as opposed to being true). The strategy of emphasizing the wickedness and misery of men was employed when "religion stood entirely upon temper and education." ${ }^{12}$ By education, Philo is referring to the use of rhetoric to foster belief, as opposed to argument and reason. A sense of melancholy is useful to drive people towards religion - through the narrative of sin, salvation and sanctification. However, the divines of Philo's time changed their style and emphasized the view that good predominates evil. That is, when emphasizing the wickedness of men was more useful (to bring about melancholy), they used rhetoric to exaggerate the ills of men. ${ }^{13}$ However, when they find that such a position was less tenable (as their audience matured in their reasoning skills), they instead focus on preaching about the pleasures of this life. In this, Hume condemns the use of rhetoric for indoctrination, especially when it is contrary to reason. ${ }^{14}$

There are at least two obvious possibilities, then, that may account for what is going on in DNR 11. On one reading, Hume is willing to use rhetoric insofar as it supports an argument that he is able to endorse (the Coherence Interpretation will be explored in the next section). As such, he distinguishes himself from the divines who use rhetoric at the expense of argument by demonstrating the use rhetoric in addition to argument. On a second reading, Hume decries the use of any rhetoric in promoting belief. This reading is more consistent with his claim that he "shall not employ any rhetoric in a philosophical argument, where reason alone ought to be hearkened

\footnotetext{
12 The weakness of 'education' here seems to resemble Hume's comments in the Treatise: that education's "maxims are frequently contrary to reason, and even to themselves in different times and places, it is never upon that account recogniz'd by philosophers" (THN 1.3.9.19). This is compatible with the view suggested by many commentators, that by education, "Hume is only referring here to indoctrination or to the blind acceptance of testimony" (O Brien' 2017, 619).

${ }^{13}$ It is interesting to observe that Philo distinguishes his use of rhetoric in DNR 10.2 ("just representations of the misery and wickedness of men") with the divine's use of rhetoric in DNR 11.20 ("exaggerate all the ills and pains"). ${ }^{14}$ Hanvelt 2012, 40.
} 
to" (FE 111). But how does this reading square with the appearance that Hume himself is using rhetoric? The answer is that Hume's use of rhetoric is simply to mock the divines. He mirrors what the divines are doing to support an opposite conclusion from theirs. Hume uses rhetoric to promote the belief that evil prevails against good, in opposition to divines who use rhetoric to promote the belief that good prevails against evil. But his argument is insincere, used to reveal the illegitimacy of the rhetorical strategy.

The Rhetorical Interpretation accounts for the weaknesses in the evidential argument. Hume is not endorsing the evidential argument; he is using it as a rhetorical strategy to reveal something about the use of rhetoric. Philo's (or Hume's) insincerity is consistent with Cleanthes' response to Philo's argument, who remarks to Demea that Philo "has been amusing himself at both our expence" (DNR 11.19) and perhaps it is the reason why Demea chooses to leave the conversation (DNR 11.21).

And consider Hume's use of rhetoric in DNR 11.13. After drawing the conclusion to the inferential argument in DNR 11.12, and before drawing the conclusion to the evidential argument in DNR 11.14-15, Philo exclaims:

Look round this universe. What an immense profusion of beings, animated and organized, sensible and active! You admire this prodigious variety and fecundity. But inspect a little more narrowly these living existences, the only beings worth regarding. How hostile and destructive to each other! How insufficient all of them for their own happiness! How contemptible or odious to the spectator! The whole presents nothing but the idea of a blind Nature, impregnated by a great vivifying principle, and pouring forth from her lap, without discernment or parental care, her maimed and abortive children. (DNR 11.13) 
It is unclear how DNR 11.13 contributes to the conclusion of Philo's evidential argument. And Philo adopts a unique style of expression in this passage. He changes his tone and uses stronger and more metaphorical language - almost, as it were, to create strong imagery for the imagination of his hearers. ${ }^{15}$

And consider the style of rhetoric Hume adopts in DNR. Hanvelt argues that, for Hume, "Effective rhetoric requires that the orator engage the imagination of the audience members because people are less convinced by an argument that is spoon fed to them than they are when they feel that they have connected the dots themselves" (Hanvelt 2012,50). This seems to be what Philo is doing in DNR 11.13, beginning with his challenge to "Look round this universe." Philo challenges his audience to participate in the dialogue, to allow them to "feel that they have connected the dots themselves."

One might object to the Rhetorical Interpretation by denying that Hume is in fact, enumerating the evils in their proper colors. First, if Hume were enumerating the evils, he would expand on the list cited in the Fragment: "racks, gravels, infamy, solitude, and dungeons" (FE 111). But he does not do so. Second, there may be an important difference between enumerating evils and enumerating the causes of evils. In the inferential argument Hume enumerates the four circumstances on which evils depend (DNR 11.5).

Nevertheless, a proponent of the Rhetorical Interpretation could respond that when Hume presents the circumstances on which evils depend, he enumerates the evils in the course of doing

\footnotetext{
${ }^{15}$ My reading here differs from Kraay. Kraay, too, attempts to account for the difficulty in interpreting DNR 11.13 by arguing that Philo is here parodying Cleanthes. He does so by point to the "remarkable" similarity between DNR 11.13 and DNR 3.7 (Kraay 2003). However, an important dissimilarity between the two texts is the style Philo adopts in DNR 11.13. Due to this, I propose an alternative interpretation. Philo is, indeed, parodying an audience, but in this case, he is using rhetoric (unsupported by reason) to parody the divines who also use rhetoric (unsupported by reason) to persuade their hearers. His target here is not Cleanthes but religious leaders.
} 
so. In fact, if the evidential argument is a mask for employing the rhetorical strategy, we would expect Hume to enumerate the evils in the course of presenting a different argument, as opposed to being plain about it. Being plain, after all, would be a poor use of rhetoric. ${ }^{16}$

\section{Coherence Interpretation}

The Evolutionary Interpretation emphasizes argument while the Rhetorical Interpretation emphasizes rhetoric; but perhaps Hume is using argument and rhetoric at the same time. On the Coherence Interpretation, while Hume is cautious about the use of rhetoric, he is willing to employ it if it supports philosophical argument. That is, rhetoric ought to be used only when accompanied by reason. The Coherence Interpretation explains Hume's reluctance to employ the rhetorical strategy in the Fragment, where rhetoric yields a different conclusion from reason. He is unwilling to use rhetoric to promote false beliefs. However, when rhetoric can promote true beliefs, it is an effective and proper tool. According to Hume's psychology, rhetoric (which triggers the imagination), rather than argument and reason, motivates belief. If reason is insufficient to produce true belief, then rhetoric (among other things) must play a supporting role. By ensuring that good arguments are presented with eloquence, rhetoric moves people to believe that which is wellreasoned. On this account, Hume both develops his argument from the Fragment, and makes use of rhetoric in order to drive his point home in DNR 11.

Because this reading is committed to the claim that Hume endorses the philosophical value of the evidential argument, it is vulnerable to the criticisms made against the Evolutionary Interpretation. More specifically, the Coherence Interpretation assumes that, in order for Hume to employ rhetoric in the evidential argument, he must endorse the evidential argument. However,

\footnotetext{
${ }^{16}$ According to Hanvelt, Hume thinks that "concealment contributes to the effectiveness of rhetoric. The greater the audience members' awareness of the artifice in an orator's rhetoric, the less naturally will they feel the passions excited by the orator, and therefore, the less powerful will be the effect of words on the passions" (Hanvelt 2012, 47).
} 
given the concerns about the evidential argument itself, Hume should not endorse this argument, and thus, should not employ rhetoric in support of it.

Alternatively, Hume is sincere in endorsing the inferential argument in the Dialogues, he endorses the argument, and, in employing the rhetorical strategy of enumerating the evils, Hume uses rhetoric in support of reason. However, after establishing this conclusion, he decides to make fun of the divines. He then uses rhetoric in the manner of the divines in the guise of the evidential argument. On this reading, Hume displays the way rhetoric ought to be used when presenting the inferential argument and then displays how rhetoric ought not be used when he mocks the rhetoric of the divines in the evidential argument. The inferential and evidential arguments have different aims and are directed at different audiences.

\section{Hume on Rhetoric, the Imagination and Education}

Each of these interpretations has important implications for Hume's views on religious education in general, and education more broadly. Hume presents the Dialogues as a conversation between Philo, Demea and Cleanthes, observed by a pupil, Pamphilus. Presumably, the conversation is aimed at the education of Pamphilus. ${ }^{17}$

If the Evolutionary Interpretation is correct, rhetoric has no place in education. Education should be about good arguments. Following the Hume of the Fragment, Philo, does not "employ any rhetoric in a philosophical argument, where reason alone ought to be hearkened to" (FE 111). This view is supported in a letter from Hume to Gilbert Elliot where Hume writes, regarding

17 (Black and Gressis 2017, 245). See Krause 2016 for a helpful discussion of the role of Pamphilus in the Dialogues. Krause writes, "in a significant sense, Philo's target audience turns out to be Pamphilus, who (together with Hermippus) symbolizes an emerging generation of thinkers, carrying Philo's influence forward. While aspects of Philo's message are lost on Demea and Cleanthes, Hume repeatedly signals that Pamphilus, of all the characters, most fully appreciates Philo's teachings" (Krause 2016, 189) 
metaphysics and theology, that "Nothing there can correct bad reasoning but good reasoning: and sophistry must be opposed by syllogism" (HL 118). Thus, Philo, in response to the bad reasoning of his audience (Demea and Cleanthes, and the divines), employs only good reasoning as a corrective. Concerned with the proper education of Pamphilus, Philo refuses to employ rhetoric in a philosophical argument (unlike the divines), and, in DNR 11, he is merely presenting Pamphilus with arguments, which Philo genuinely endorses. Hume does not therefore show disdain for all kinds of education. Instead, Philo's education of Pamphilus provides a clear demonstration for his readers about what 'true' education ought to look like: true education is aimed at training the student through the use of good reasoning and philosophical argumentation. Rhetoric has no place in education where the student's mind ought only to be focused on philosophical argumentation.

From the viewpoint of education, however, one might be concerned about the effectiveness of moral education that employs only philosophical argumentation without the use of rhetoric. Assuming that the goal of moral education is not merely to increase one's moral knowledge (construed as propositions about what we ought to do) but also to motivate moral behavior, and since Hume thinks that passions rather than reason motivates moral action, we would have good reason to be sceptical about the effectiveness of the kind of moral education which employs only philosophical argumentation.

If, however, the Rhetorical Interpretation is correct, then Philo is cavalier in the education of Pamphilus. He decides to employ "rhetoric in a philosophical argument, where reason alone ought to be hearkened to." He provides a disingenuous argument (in the sense that he does not endorse the evidential argument) in order to employ the rhetorical strategy. According to this reading, Philo demotes the role of reason in education, and uses rhetoric to convince Pamphilus, 
or mock the divines, or both. Philo is clearly aware of Pamphilus' presence. ${ }^{18}$ The Rhetorical Interpretation thus implies that Philo does not take Pamphilus' education seriously. This conclusion is consistent with Cleanthes' complaint to Demea that Philo "has been amusing himself at both our expence" (DNR 11.19). This is further supported by readings on which Philo's final recommendation to Pamphilus in DNR 12.33 is disingenuous. However, given Hume's own distaste for the rhetorical methods of the divines, this reading seems unlikely, since Hume would be casting Philo in the same light as the divines. Surely, it seems implausible that Hume would paint Philo in this unfavorable light, given that, in a letter to Gilbert Elliot, he writes, "I should have taken on me the character of Philo" (HL 120).

Proponents of the Rhetorical Interpretation therefore need a different account of Philo's apparent disingenuousness. On one alternative, the conversation simply 'gets away' from Hume. Hume struggles between Philo's desire to educate Pamphilus, and Hume's other goals (such as his desire to mock the divines). On another alternative, Philo thinks that Pamphilus will catch his humor, and the use of humor and satire itself is part of Pamphilus' education. ${ }^{19}$ Finally, on a third alternative, Hume thinks that the problems of computation and comparison, and the limitations of our faculties, prevent us from justifying any belief in God's moral attributes. In such an instance, rhetoric helps us become sensible of beliefs we already possess. Or, in Philo's words, "And for that purpose a talent of eloquence and strong imagery is more requisite than that of reasoning and

\footnotetext{
${ }^{18}$ Krause 2016, 204.

${ }^{19}$ Krause's analysis seems to support this reading. Krause does think that Pamphilus understands the tactical and strategic moves that Philo makes against Demea and Cleanthes (Krause 2016, 205). In fact, Krause even provides the example of Philo's playfulness (Krause 2016, 201-205).
} 
argument. For is it necessary to prove, what every one feels within himself? 'Tis only necessary to make us feel it, if possible, more intimately and sensibly" (DNR 10.2). ${ }^{20}$

Finally, according to the Coherence Interpretation, the enumeration of evils is meant to improve the argument, but also to "gain the cause" with Philo's audience. Philo is willing to use rhetoric when it is consistent with argument. On this view, rhetoric has a place in education insofar as it is used to support the conclusions of a well-reasoned argument. Education consists in the use of reason (to provide justification for claims) and, where relevant (in support of reason), the use of rhetoric (to activate the imagination, and promote belief). Consequently, we might summarise the distinct implications that each interpretation has for Hume's view on education:

\begin{tabular}{|l|l|}
\hline Evolutionary Interpretation & $\begin{array}{l}\text { Rhetoric should never be employed in education, even when } \\
\text { supported by philosophical argument. }\end{array}$ \\
\hline Rhetorical Interpretation & $\begin{array}{l}\text { Rhetoric can be employed in education, regardless of } \\
\text { whether it is supported by philosophical argument. }\end{array}$ \\
\hline Coherence Interpretation & $\begin{array}{l}\text { Rhetoric should only be employed in education when } \\
\text { supported by philosophical argument. }\end{array}$ \\
\hline
\end{tabular}

In my view, while all three accounts have some plausibility, the Coherence Interpretation is more promising than the Evolutionary and Rhetorical Interpretations. In addition to the concerns discussed above, the Rhetorical Interpretation seems to violate the principle of charity: Philo (and Hume) is presented as being disingenuous, and one might wonder, if we are willing to concede that Hume is willing to use rhetoric at the expense of reason, how reliable and sincere much of his

${ }^{20}$ This account is compatible with the view that Hume thinks that we possess 'natural beliefs'. In which case, rhetoric is a tool to activate these natural beliefs. 
other arguments are. In this sense, the Rhetorical Interpretation appears to give up too much. Additionally, the Coherence Interpretation is preferable to the Evolutionary Interpretation as it is able to provide a more robust account of the role of rhetoric in moral education. Given the importance of the passions in motivating moral behavior, and the way that rhetoric and eloquence moves the imagination and, relatedly, the passions in Hume's moral psychology, it follows that a positive view of rhetoric within the context of moral education allows for a moral education that takes into account moral cultivation as well. For these reasons, the Coherence Interpretation seems most plausible to me.

In this paper, I have outlined three views of the role of rhetoric in philosophical or religious education: that rhetoric has no place in education, that rhetoric is relevant only when it is supported by reason, and that rhetoric can be employed to promote beliefs even when it is not supported by reason (especially in issues where mitigated sceptical reasons, such as the limitation of our faculties, might prevent us from fully justifying beliefs). In this, I hope to have provided a plausible interpretation of the final segment of the Fragment which has received very little attention in the secondary literature. I hope also to have proposed a novel approach to understanding the relationship between the inferential and evidential arguments in the Dialogues, as well as the relationship between philosophical argument and rhetoric in Hume's views on (religious) education. Hume's own interest in rhetoric and eloquence is evident in his writings, and in my opinion, paying attention to Hume's use of this literary tool will help provide a more robust understanding of Hume's own writings, and perhaps, the dialogues and conversations that was taking place within the same historical context. 


\section{References}

Black, Tim, and Robert Gressis. 2017. “True religion in Hume's Dialogues Concerning Natural Religion." British Journal for the History of Philosophy 25.2: 244-264.

Clark, Samuel. 2013. “Hume's Uses of Dialogue.” Hume Studies 39.1: 61-76.

Hanvelt, Marc. 2012. The Politics of Eloquence: David Hume's Polite Rhetoric. Toronto: University of Toronto Press.

Hume, David. 1739-1740/1975. A Treatise of Human Nature. Edited by L. A. Selby-Bigge, 2nd ed. revised by P. H. Nidditch. Oxford: Clarendon Press.

Hume, David. 1741-1742/1987. Essays Moral, Political, and Literary. Edited by Eugene F. Miller. Indianapolis: Liberty Classics.

Hume, David. 1748/2008. An Enquiry concerning Human Understanding. Edited by Peter Millican. Oxford: Oxford University Press. 
Hume, David. 1757/ 2007. A Dissertation on the Passions: The Natural History of Religion: A Critical Edition. Edited by Tom Beauchamp. Oxford: Oxford University Press.

Hume, David. 1779/2007. Hume: Dialogues Concerning Natural Religion and other writings. Edited by Dorothy Coleman. Cambridge: Cambridge University Press.

Holden, Thomas. 2010. Spectres of False Divinity: Hume's Moral Atheism. Oxford: Oxford University Press.

Kraay, Klass J. 2003. "Philo’s Argument for Divine Amorality Reconsidered." Hume Studies 29: 283-304.

Krause, Jonathan Harold. 2016. “The Political Lessons of Hume's Dialogues Concerning Natural Religion." Hume Studies 42.1-2: 187-211.

Lorkowski, C. M. 2016. "Doxastic Naturalism and Hume's Voice in the Dialogues.” The Journal of Scottish Philosophy 14.3: 253-274.

Morrisroe Jr., Michael. 1969. “Rhetorical Methods in Hume's Works on Religion.” Philosophy \& Rhetoric 2.3, 121-138.

O’ Brien, Dan. 2003. “Hume on Education.” Pacific Philosophical Quarterly 98.1: 619-642. 
Stewart, M. A. 1995. “An early fragment on evil.” In Hume and Hume’s connexions, edited by M. A. Stewart and John P. Wright, 160-170. Pennsylvania: Pennsylvania University Press.

Stewart, M. A. 2003. "Religion and rational theology" in The Cambridge Companion to the Scottish Enlightenment. Edited by Alexander Broadie. Cambridge: Cambridge University Press.

Stewart, M. A. 2005. “Hume's Intellectual Development, 1711-1752” in Impressions of Hume. Edited by Marina Frasca-Spada and P. J. E. Kail. Oxford: Oxford University Press. 